\title{
Composition of the Kirsten Skeletal Collection at Stellenbosch University
}

\section{AUTHORS: \\ Amanda Alblas ${ }^{1}$ \\ Linda M. Greyling \\ Elsje-Marie Geldenhuys ${ }^{1}$}

\section{AFFILIATION:}

'Division of Anatomy and Histology, Department of Biomedical Sciences, Stellenbosch University, Cape Town, South Africa

\section{CORRESPONDENCE TO:}

Amanda Alblas

\section{EMAIL:}

aa2@sun.ac.za

\section{DATES:}

Received: 08 June 2017

Revised: 11 Aug. 2017

Accepted: 15 Aug. 2017

\section{KEYWORDS:}

physical anthropology;

South African coloured population; skeletal reference collection; regional and ancestral specific skeletal standards

\section{HOW TO CITE:}

Alblas A, Greyling LM, Geldenhuys E. Composition of the Kirsten Skeletal Collection at Stellenbosch University. S Afr J Sci. 2018;114(1/2), Art. \#2017-0198, 6 pages http://dx.doi.org/10.17159/ sajs.2018/20170198

\section{ARTICLE INCLUDES: \\ $\times$ Supplementary material $\times$ Data set}

\section{FUNDING:}

None

(C) 2018. The Author(s). Published under a Creative Commons Attribution Licence.
The Kirsten Skeletal Collection is curated in the Division of Anatomy and Histology, Faculty of Medicine and Health Sciences, Stellenbosch University, South Africa. It comprises the largest documented cadaver-derived South African coloured skeletal collection in the world. Our aim in this paper is to present an inventory and characterise the identified skeletons in the Kirsten Skeletal Collection as well as provide a descriptive indication of what researchers can expect to encounter at the anthropology unit at Stellenbosch University. The skeletal material was derived mainly from the cadaver donation programme of the Division of Anatomy and Histology over a 58-year period (1957-2015). All pertinent information for each individual skeleton is entered into a database and a full skeletal inventory is established. The skeletal database registry was analysed to demonstrate the distribution of age, sex and population affinity of individuals in the collection. Currently, this collection consists of 1161 skeletons with known records. Despite differences in the age and sex composition, the skeletal profile in general reflects mainly the profile of the Western Cape population. Most individuals were born between 1920 and 1950, placing the Kirsten Skeletal Collection in the early to mid-20th century. The age at death for the greatest proportion (41.8\%) of individuals was between 40 and 60 years. Current biological profile techniques in age, ancestry and sex estimation can be improved and, among others, new regional and ancestral specific standards for the biologically unique and diverse South African coloured population can be developed.

\section{Significance:}

- We present the largest documented skeletal collection of the South African coloured population in the world.

- This work contributes to the skeletal reference database for use by physical anthropologists and others.

\section{Introduction}

Human skeletal collections with known records are valuable for both teaching and research. Current research using human skeletal collections includes developing new techniques to test and standardise regional-specific data regarding osteometric measurements and physical observations. ${ }^{1-5}$ These reference points provide practical information for the estimation of biological profiles of unknown skeletons ${ }^{6}$ in both forensic anthropology and bioarchaeology, including estimation of age, sex and stature. Detailed descriptions of skeletal remains of known populations are used to confirm or contradict archaeological and social theories for past and present communities. ${ }^{2}$ Studies on skeletal collections include the physiological stresses and diseases experienced by the community that may have influenced their health status and physical attributes.

Nationally, the South African population was estimated to be almost 52 million people during the 2011 physical census. South African blacks constitute the largest population group in the country at $79.2 \%{ }^{7}$ However, the regional population demographic of the Western Cape Province consists of $32.9 \%$ South African black, $15.7 \%$ South African white and $48.8 \%$ South African coloured. Unlike other provinces in South Africa, the Western Cape Province is composed of primarily the self-identified social group called 'South African coloureds'. ${ }^{6}$ The Kirsten Skeletal Collection is reasonably representative of the Western Cape with mainly South African coloured individuals, providing a standard database of this area in South Africa. Although the Kirsten Skeletal Collection was established in the late 20th century, it is only in recent years that skeletons were intentionally added to the Collection for the purposes of research.

Our aim in this paper was to present an inventory of the osteological material in the Kirsten Skeletal Collection at Stellenbosch University and provide descriptive information to both national and international researchers interested in anthropological studies of the biologically heterogeneous South African coloured population.

\section{Population demographic origin}

South Africa is a multicultural nation with a rich biological history. For centuries, the southwestern corner of Africa was home to the oldest known lineage of modern humans ${ }^{8,9}$ - descendants of the original Khoikhoi (pastoralists) and the San (hunter-gatherers) populations ${ }^{10}$. These two historical groups are collectively referred to as the Khoisan or the Khoe-San, and speak a distinctive click language. ${ }^{11}$ Although the Khoisan maintained an isolated ancient lifestyle for centuries and remained genetically distinct with unique physical characteristics from Europeans, Asian and other Africans ${ }^{8}$, the genetic profiles of some tribes (such as the Khwe groups) show high proportions of Bantuspeaking admixture ${ }^{10,11}$.

Linguistic and archaeological evidence indicates that the South African black population originated from the NigerCongo linguistic phylum in the Cameroon-Nigeria grasslands. They migrated as part of the greater Bantu group to occupy much of the east and southern parts of Africa. ${ }^{12,13}$ Variants from this Bantu family in the south included the Nguni group (Xhosa, Zulu, Swati and Ndebele tribes) and the Southern (also called the Sotho-Tswana) groups (Southern Sotho, Northern Sotho, Tswana, Venda and Tsonga tribes). ${ }^{12,14,15}$ 
The Nguni populations migrated southwards over many centuries with large herds of Nguni cattle. These migration patterns started around 2000 years ago followed by larger migration impressions around 1400 CE. ${ }^{14,16}$ When entering southern Africa, settlement patterns among the different tribes formed as a result of the settling of some groups along the way, while others kept moving; for example the Ndebele stayed in the north, the Swazi in the northeast, the Zulu towards the east and the Xhosa in the south. ${ }^{12}$

Historical documents indicate that Portuguese sailors in the 1400s were the first Europeans to have contact with these tribes. The European community settled at the Dutch-controlled Cape Colony between 1652 and the 19th century. Other immigrant groups were mainly descended from the French, Germans, Greeks and Italians. The British settlers colonised the Cape in the mid-1800s. ${ }^{17,18}$ The Indian/Asian population originated from Indian and Chinese immigrants, as well as slaves imported to relieve the labour burden in the fast-growing Cape settlement. These slaves were shipped to the Cape colony from Indonesia, southern China and Madagascar, among others. ${ }^{18,19}$

Marriages amongst white European men and women from either the free black populations or Khoisan were common during the early Dutch settlement era. ${ }^{17,20}$ Colonisation and migration from many parts of the world became the foundation to modern variation in South African groups, and produced a heterogeneous new population with distinctive physical and biological traits and genetic variations. ${ }^{6}$ As a result of the eradication of slavery in 1834-1938, the newly formed self-identified population was named the Cape Coloureds, ${ }^{17,18}$ and is today known as the South African coloured population. During the early 1800 s, the number of cross-cultural relationships declined ${ }^{21}$, and later during the 1900s, racism established by apartheid laws further reduced crosspopulation gene flow $\mathrm{w}^{6,22}$

Apartheid in South Africa was a system of racial separation that was enforced by the minority governing party (the white population) that ruled between 1948 and 1994. ${ }^{22,23}$ Under this ruling, African people that were a product of the Bantu expansion, were grouped as black people, while people with an admixture of mixed origin, including Khoisan, were classified as coloureds. ${ }^{20}$ The Population Registration Act of 1950 was used to categorise all South Africans as black, white, Indian or coloured during the apartheid reign ${ }^{20}$ Census in the apartheid era was underreported, particularly concerning the black population because of legislation such as the Native Areas Amendment Bill and the Group Areas Act. Such legislation resulted in the number of people in South Africa being grossly underestimated. ${ }^{24}$ The apartheid laws were introduced to force population segregation by assigning certain areas for each population group. This forced segregation with geographical parting of these groups directly limited admixture of different population groups. ${ }^{6,22}$ Although apartheid was abolished in 1994, the different populations in South Africa have tended to persist within their socially defined population groups, keeping the different populations largely segregated from one another. ${ }^{6,25}$ As a result of limited interracial relationships still today, genetic variation within groups is decreasing and variation between groups is increasing ${ }^{6,25}$

\section{Materials and methods}

\section{Acquisition and processing of skeletal material for the Collection}

The Department of Anatomy (later changed to the Division of Anatomy and Histology) at Stellenbosch University was established in 1957. Initially, medical students were trained under the guidance of Professor J.F. van E. Kirsten in the Mike de Vries building (formerly known as D.F. Malan building) on the main campus located in Stellenbosch, South Africa. Kirsten, a qualified general surgeon, was one of the first five professors appointed at the newly established medical faculty, and the first to perform the task of collecting skeletal material for study. The anatomy department relocated over time - initially to Karl Bremer Hospital in Bellville and then, during the 1970s, to the Tygerberg Medical Campus adjacent to the then newly built Tygerberg Hospital. It was during this time that the J.F. van E. Kirsten Museum of Morphology and the Kirsten Skeletal Collection was established, in Kirsten's honour. The initial cadavers used for anatomy training of medical students at Stellenbosch University were received from the University of Pretoria and the University of the Witwatersrand from 1957 to 1960. The first cadavers embalmed at Stellenbosch University's Department of Anatomy were received from Karl Bremer Hospital in 1960. From 1957 onwards, a number of the dissected cadavers were skeletonised, except during a brief period in the 1990s when the Department did not have the capacity or staff to skeletonise cadavers. Between 30 and 40 skeletons are currently added to the collection on an annual basis.

Under the Human Tissue Act, Act 65 of $1983^{26}$, the more recent National Health Act $^{27}$ (Act 61 of 2003), and the protection of the regional Inspector of Anatomy, the Division of Anatomy and Histology is allowed to receive cadavers for both teaching and research purposes. The cadavers received are either consented donations or unclaimed bodies of persons who died from natural causes in the Western Cape region, specifically the Northern suburbs of Cape Town and surrounding rural towns. Consented donations are individuals (or their family members) who bequeathed their bodies to the University. So-called 'unclaimed' bodies are those for whom no next-of-kin could be traced, either by the institution at which the person died or by any other means. Unclaimed does not necessarily imply that the person is unknown. If, however, family or friends are traced at a later stage when the cadaver is already prepared at the Division, whoever lays legal claim to the body is allowed to remove it for burial. The majority of unclaimed bodies received are from communities with a low socio-economic status. The cadaver intake does not include any unnatural or traumatic deaths as South African legislation requires that all bodies resulting from unnatural deaths be autopsied by the Forensic Pathology Services. ${ }^{28}$ Autopsied bodies cannot be embalmed, therefore these bodies cannot be entered into the cadaver programme. Although the skeletal collection consists largely of individuals obtained through this cadaver intake programme, a small number of unidentified fragmented individuals with archaeological or forensic (cases received for biological profile assessment from the police) origins are present in the collection. Past curators accessioned these remains into the collection. Material accessioned in the collection cannot be removed from the database; however, these materials are not used for purposes of research.

Cadavers are used for dissection in the anatomy training of undergraduate and postgraduate medical and allied healthcare students. Upon intake at the Division of Anatomy and Histology, all personal information available on the cadaver, as well as the intake number given to the cadaver, is recorded in the cadaver register of the Division. This information includes age, sex, date of birth, date of death, last known residential address, hospital/funeral home from which the body was acquired and previously self-identified ancestry. Medical records of the individuals are not made available; only cause of death is provided. Since 2011, intake information has included the person's weight at reception and full-face and profile photographs. The cadavers are subsequently embalmed and stored. Before the cadavers are used, a full-body X-ray is taken using Lodox $^{\circledR}$ Statscan ${ }^{\circledR}$ digital imaging system (Figure 1a). After dissection, excess soft tissue is manually removed from the cadavers and the bones are immersed in water. The remains are carefully boiled at relatively low temperature $\left(60-80^{\circ} \mathrm{C}\right)$. Following the boiling process, the remaining tissue on the bones is removed with a scalpel and forceps, whereafter the bones are washed with warm soapy water, and a scrubbing brush is used to lightly scour the surfaces of the bones until smooth. The bones are then air dried at room temperature and bleached with a bleaching agent. The Kirsten Collection intake number is then recorded on each dried bone with a permanent marker.

The processed skeletal material is registered and curated at the Kirsten Skeletal Collection Ossuary at the Division of Anatomy and Histology. All pertinent information for each individual skeleton is entered into a database and a full skeletal inventory is established. At least 350 complete skeletons in anatomical order have been scanned with the Lodox ${ }^{\circledR}$ Statscan ${ }^{\circledR}$ since 2014 (Figure 1b). The practice of correlating these scans with the cadaver scans taken prior to maceration will continue. Projects have been initiated in collaboration with radiologists 
to use these scans to compare disease lesions on bone, and in collaboration with forensic anthropologists to use these scans to set sciencebased X-ray standards for identifying human remains.

This study on the skeletal material was ethically cleared by the Health Research and Ethics Committee of Stellenbosch University and conforms to the principles stipulated by the Declaration of Helsinki (1964). The allocated ethics number is $S 13 / 05 / 100$.

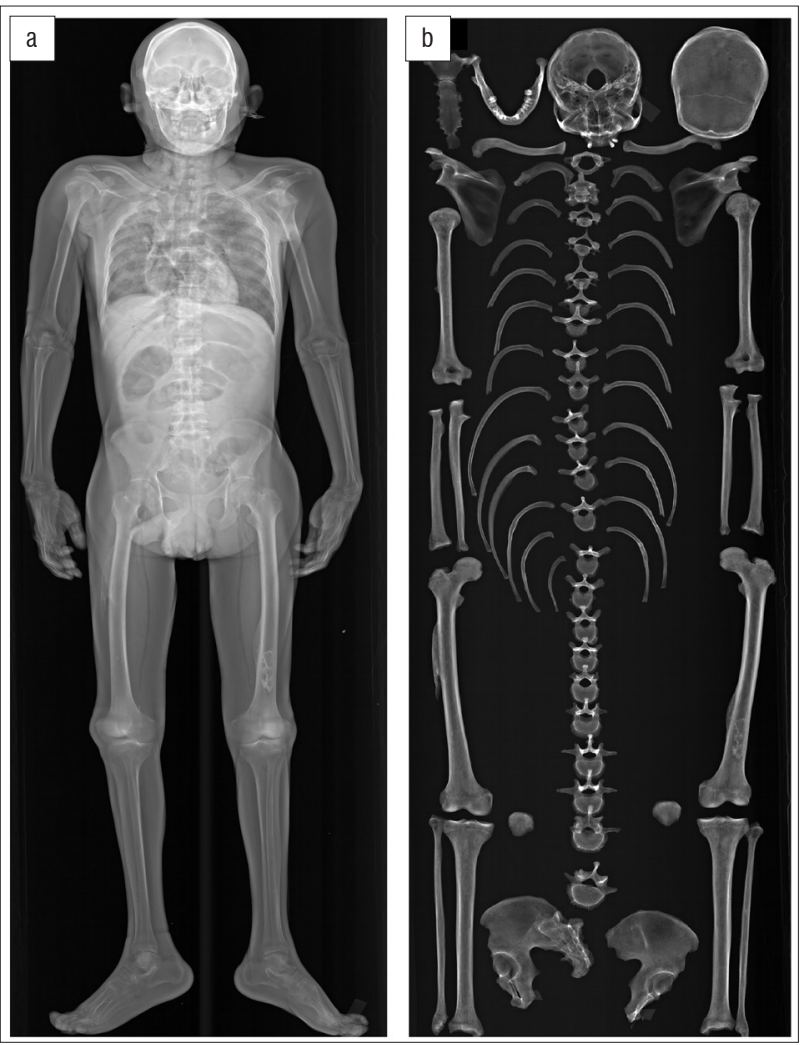

Figure 1: $\quad$ Cadaver K96/13 received in 2013: (a) Lodox ${ }^{\circledR}$ scan of cadaver prior to dissection by medical students and (b) Lodox ${ }^{\circledR}$ scan of skeleton in anatomical order (anthropology number An1352).

\section{Results}

The Kirsten Skeletal Collection currently consists of 1161 skeletons, which, according to the known cadaver records, represent mostly individuals from the Western Cape Province, South Africa. Although the overall preservation of the skeletal elements is good, loans to students, other departments and institutions in the past, have resulted in total or partial loss of some of the material, which has reduced the number of full skeletons available for study. As a result, the collection currently has 674 (58\%) complete and 342 (29.5\%) incomplete individuals from the cadaver programme. However, 103 (8.9\%) cadaver-derived individuals are on loan or at an unknown location. Moreover, this collection hosts a small number (3.6\%) of fragmented individuals with archaeological or forensic origins (Table 1).

The greatest proportion (42\%) of individuals in the collection were born between 1920 and 1949, with the oldest born in 1855 and the most recent in 1991. Most (54.1\%) individuals in the collection died between 1970 and 1989 (Figure 2).

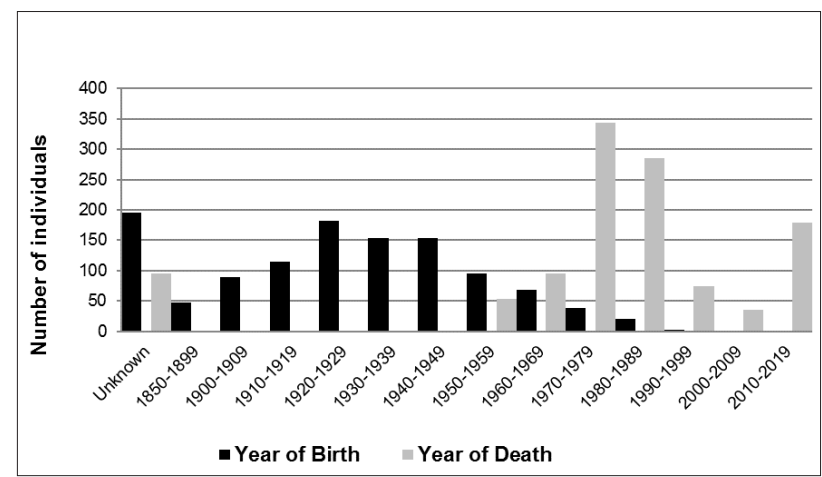

Figure 2: Frequency distributions for year of birth and year of death for the skeletons in the Kirsten Skeletal Collection.

The collection comprises individuals from three main socially defined population groups, namely South African coloured (59.7\%), South African black (16.5\%) and South African white (12.2\%). The regional population composition of the Western Cape Province differs considerably from that of other provinces in South Africa. According to the census of $2011^{7}$, the black population group has the highest proportion (of over $79 \%$ ) in all provinces with the exception of the Western Cape (32.9\%). The South African coloured population is the highest proportion in the Western Cape (48.8\%). Therefore, it is expected that a larger South African coloured population is apparent in the Kirsten Skeletal Collection, which is derived mainly from Western Cape individuals. However, the South African coloured population in the Western Cape declined from $58.3 \%$ in $1991^{24}$ to $48.8 \%$ in $2011^{7}$

Cadavers were mostly acquired from the large teaching hospitals in the region, namely Tygerberg Hospital (32\%), followed by Karl Bremer Hospital (10.1\%), both in the Bellville area, and Groote Schuur Hospital $(6.8 \%)$ in Cape Town. A total of $15.6 \%$ of individuals were received directly from undertakers as paupers and $14.6 \%$ were from unknown sources or sources that had not been documented (Table 2). Available records for the last residence of individuals in the Kirsten Skeletal Collection indicate that the greatest proportion were from the Cape Town metropole (42.3\%) and surrounding towns (19.1\%) (Table 3).

Table 1: The state of the skeletal remains in the Kirsten Skeletal Collection

\begin{tabular}{l|l|c}
\hline \hline \multicolumn{1}{c|}{ State } & \multicolumn{1}{c}{ Description } & \multicolumn{1}{c}{$\boldsymbol{n}$ (\%) } \\
\hline Complete & A complete individual that may be either articulated or unarticulated & 674 (58.0) \\
\hline Incomplete (cranial only) & A complete skull (calvarium, cranium and mandible) without associated post-cranial remains \\
\hline Incomplete (fragmented) & $\begin{array}{l}\text { Remains that have only a few bones present because specific bones are on loan to institutions, departments or } \\
\text { students on a semi-permanent basis or have been lost through loan to students }\end{array}$ & 197 (16.2) \\
\hline Incomplete (post-cranial only) & Post-cranial remains which are not associated with a skull & 85 (7.3) \\
\hline On loan (complete) & $\begin{array}{l}\text { Complete remains that are on loan to institutions, departments or students on a semi-permanent basis, either } \\
\text { articulated or unarticulated }\end{array}$ & 58 (5.0) \\
\hline Missing/unknown & Remains for which the current location is unknown & 45 (3.9) \\
\hline Archaeological/forensic origin & Skeletons received from sources other than the cadaver programme \\
\hline
\end{tabular}


Table 2: $\quad$ Locations or institutions from which bodies were received

\begin{tabular}{|c|c|}
\hline Location/institution & $n(\%)$ \\
\hline Tygerberg Hospital & $379(32.6)$ \\
\hline Karl Bremer Hospital & $117(10.1)$ \\
\hline Groote Schuur Hospital & $79(6.8)$ \\
\hline Paarl Hospital & $51(4.4)$ \\
\hline Tuberculosis institutes & $23(2.0)$ \\
\hline Conradie Hospital & $22(1.9)$ \\
\hline Stellenbosch Hospital & $19(1.6)$ \\
\hline Victoria Hospital & $16(1.4)$ \\
\hline Stikland Hospital & $15(1.3)$ \\
\hline Hottentots Holland Hospital & $14(1.2)$ \\
\hline Somerset Hospital & $13(1.1)$ \\
\hline Brooklyn Chest Hospital & $12(1.0)$ \\
\hline Eerste River Hospital & $12(1.0)$ \\
\hline Valkenberg Hospital & $9(0.8)$ \\
\hline Western Cape mortuaries & $5(0.4)$ \\
\hline Undertakers & $181(15.6)$ \\
\hline Other & $25(21.1)$ \\
\hline Unknown & $169(14.6)$ \\
\hline
\end{tabular}

Table 3: $\quad$ Last available residence (region) of individuals in the Kirsten Skeletal Collection

\begin{tabular}{|c|c|}
\hline Last residence & $n(\%)$ \\
\hline \multicolumn{2}{|l|}{ South Africa } \\
\hline Cape Town Metropole: Cape Flats & $175(15.1)$ \\
\hline Cape Town Metropole: Northern suburbs & $155(13.4)$ \\
\hline Stellenbosch/Paarl Districts & $114(9.8)$ \\
\hline Kuils River/Kraaifontein & $93(8.0)$ \\
\hline Cape Town Metropole: Southern suburbs & $92(7.9)$ \\
\hline Other Western Cape towns & $65(5.6)$ \\
\hline Somerset West District & $51(4.4)$ \\
\hline Wellington/Worcester Districts & $21(1.8)$ \\
\hline Southern Cape & $11(0.9)$ \\
\hline Eastern Cape & $10(0.9)$ \\
\hline Northern Cape & $6(0.5)$ \\
\hline Free State & $2(0.2)$ \\
\hline Namibia & $11(0.9)$ \\
\hline Unknown & $355(30.6)$ \\
\hline
\end{tabular}

Table 4: Population and age composition of the individuals in the Kirsten Skeletal Collection

\begin{tabular}{|l|c|c|c|c|c|c|c|c|c|c|c|c|c}
\hline \hline & $\boldsymbol{n}(\%)$ & BM & BF & WM & WF & CM & CF & KM & KF & KU & UM & UF & US \& UA \\
\hline Unknown & $172(14.8)$ & 9 & 4 & 3 & 2 & 24 & 6 & 0 & 0 & 10 & 4 & 2 & 109 \\
\hline Infant (birth -5 years) & $0(0)$ & 0 & 0 & 0 & 0 & 0 & 0 & 0 & 0 & 0 & 0 & 0 & 0 \\
\hline Juvenile (5.1-15 years) & $6(0.5)$ & 1 & 1 & 0 & 0 & 1 & 3 & 0 & 0 & 0 & 0 & 0 & 0 \\
\hline Sub-adult (15.1-20 years) & $11(1.0)$ & 3 & 0 & 0 & 0 & 5 & 3 & 0 & 0 & 0 & 0 & 0 & 0 \\
\hline Young adult (20.1-40 years) & $232(20.0)$ & 39 & 11 & 4 & 0 & 93 & 81 & 0 & 1 & 2 & 1 & 0 & 0 \\
\hline Adult (40.1-60 years) & $485(41.8)$ & 76 & 17 & 35 & 14 & 240 & 98 & 0 & 0 & 0 & 1 & 1 & 2 \\
\hline Old adult (60.1-80 years) & $222(19.1)$ & 25 & 3 & 40 & 28 & 94 & 31 & 1 & 0 & 0 & 0 & 0 & 0 \\
\hline Very old (80.1-105 years) & $33(2.8)$ & 3 & 0 & 5 & 11 & 7 & 7 & 0 & 0 & 0 & 0 & 0 & 0 \\
\hline Total & $\mathbf{1 1 6 1}$ & $\mathbf{1 5 6}$ & $\mathbf{3 6}$ & $\mathbf{8 7}$ & $\mathbf{5 5}$ & $\mathbf{4 6 4}$ & $\mathbf{2 2 9}$ & $\mathbf{1}$ & $\mathbf{1}$ & $\mathbf{1 2}$ & $\mathbf{6}$ & $\mathbf{3}$ & $\mathbf{1 0 9}$ \\
\hline
\end{tabular}

BM, black male; BF, black female; WM, white male; WF, white female; CM, coloured male; CF, coloured female; KM, Khoisan male; KF, Khoisan female; KU, Khoisan unknown sex; UM, unknown ancestry male; UF, unknown ancestry female; US, unknown sex; UA, unknown ancestry

The mean age at death for the entire collection is 51.0 years and ranges from 10 to 103 years. The greatest proportion $(41.8 \%)$ of individuals died between the ages of 40 and 60 . The mean age at death for female individuals from all population groups is 49.7 years (10 to 103 years) and for male individuals, 51.7 years (15 to 100 years) (Table 4). When comparing the age composition of the three populations (black, white and coloured), both male and female groups for the black and coloured populations show the highest proportion of individuals died in the adult (40-60 years) age category, whereas more male and female individuals in the white population were in the old adult (61-80 years) age category at death (Table 4). The average age at death for the black population was 51.0 years for males and 41.5 years for females; for the coloured population was 50.6 years for males and 45.5 years for females; and for the white population was 62.4 years for males and 66.9 years for females.

The sex ratio of the collection demographics is not representative of the South African population. Sex distribution determined by censuses ${ }^{7}$ indicate that the South African population is predominantly female. However, the female individuals in this collection are under-represented in all three population groups (coloured, black and white), with the majority $(61.6 \%)$ of skeletons being male (Table 5$)$. 
Table 5: Population and sex composition of the individuals in the Kirsten Skeletal Collection

\begin{tabular}{l|c|c|c|c}
\hline \hline Population group & $\boldsymbol{n}(\%)$ & Male & Female & Unknown sex \\
\hline Coloured & $693(59.7)$ & 464 & 229 & - \\
\hline Black & $192(16.5)$ & 156 & 36 & - \\
\hline White & $142(12.2)$ & 87 & 55 & - \\
\hline Khoisan & $14(1.2)$ & 1 & 1 & 12 \\
\hline Asian & $1(0.1)$ & 1 & 0 & - \\
\hline Unknown & $119(10.3)$ & 6 & 3 & 110 \\
\hline Total & $\mathbf{1 1 6 1 ( 1 0 0 )}$ & $\mathbf{7 1 5}$ & $\mathbf{3 2 4}$ & $\mathbf{1 2 2}$ \\
\hline
\end{tabular}

Table 6: Cause of death as stated on the death certificate

\begin{tabular}{|c|c|}
\hline Cause of death & $n(\%)$ \\
\hline Cardiovascular disease & $175(15.1)$ \\
\hline Cancer & $166(14.3)$ \\
\hline Respiratory disease without PTB & $120(10.3)$ \\
\hline Respiratory disease with PTB & $111(9.6)$ \\
\hline Brain disease/haemorrhage & $36(3.1)$ \\
\hline Cardiopulmonary failure/disease & $31(2.7)$ \\
\hline Liver cirrhosis/disease & $26(2.2)$ \\
\hline Gastrointestinal disease & $19(1.6)$ \\
\hline Renal failure & $18(1.6)$ \\
\hline Malnutrition, neglect, hypothermia & $16(1.4)$ \\
\hline Cardiovascular disease and tuberculosis & $11(0.9)$ \\
\hline Liver disease and cancer & $11(0.9)$ \\
\hline Cardiopulmonary failure and liver disease & $4(0.3)$ \\
\hline Respiratory disease and brain disease & $3(0.3)$ \\
\hline Cardiovascular disease and renal failure & $3(0.3)$ \\
\hline Cardiovascular and gastrointestinal diseases & $3(0.3)$ \\
\hline Other & $64(5.5)$ \\
\hline Unknown/natural causes & $344(29.6)$ \\
\hline
\end{tabular}

PTB, pulmonary tuberculosis

According to the death certificates on record, cause of death was mainly cardiovascular disease $(15.1 \%)$ and cancer of various origins (14.3\%), although respiratory diseases such as pulmonary tuberculosis, bronchiectasis, pneumonia and asthma accounted for a large number of intakes (24.1\%). In 344 cases (29.6\%), the cause of death was indicated as either unknown or natural causes (Table 6), as there is no obligation for clinicians to indicate true cause of death on the death notification form as legislation dictates that the HIV/Aids status of a patient should be kept confidential. ${ }^{28}$ Clinicians therefore indicate any HIV/Aids related death as natural and in this context it has the same meaning as unknown. When comparing the main cause of death across ancestral groups, heart disease was the main cause of death among the white group, while cancer was the most common cause amongst the coloured and black groups. ${ }^{24}$

\section{Discussion}

The Western Cape Province of South Africa has a rich genetic history, arising from many parts of the world including the local ancient Khoisan population ${ }^{8-11}$, the greater Bantu groups from the Niger-Congo phylum ${ }^{12,14-16}$, European settlers ${ }^{17,18}$ and slaves from the East ${ }^{18,19}$. Marriages amongst the different population groups were once common $^{17,20}$, and produced a heterogeneous new and genetically unique population in the Western Cape, until apartheid was introduced and resulted in a drastic decrease in cross-population gene flow6,20,25.

The origin of the osteological material in the Kirsten Skeletal Collection has been mainly cadavers used during anatomy training of medical students since the anatomy department's origin in the late 1950s. Research projects on this material were initiated only in recent years. ${ }^{6,22,29-32}$ These cadavers derive from consented donations or unclaimed bodies of persons who died from natural causes in the Western Cape region.

Date of birth and date of death from cadaver records indicate that the Kirsten Skeletal Collection represents an adult population from the midto late 20th century. In comparison, the Raymond A. Dart collection at the University of the Witwatersrand in Johannesburg (Gauteng Province) represents mostly a population from the early to mid-20th century ${ }^{1}$ and the Pretoria Bone Collection at the University of Pretoria ${ }^{5}$, also a mid- to late 20th century population.

While percentages from both black and coloured population groups show that the greatest proportion of male and female individuals died between 40 and 60 years of age, both male and female individuals from the white population were older than 60 years at death. This difference may be explained by socio-economic circumstances, religious beliefs and unclaimed body donation regulations., ${ }^{5,27}$ The reason for the differences in the number of male and female donations and unclaimed bodies may be cultural, as there is a tendency in the coloured group for men to leave family units, either temporarily or permanently, and not keep in communication with relatives ${ }^{25}$, and thereby end up as unclaimed bodies in the cadaver register.

Although it was expected that the Kirsten Skeletal Collection would house a larger South African coloured population group, as it is derived from primarily Western Cape individuals, some cultural groups in South Africa are less willing to donate their bodies to science than others. Although organ donation is allowed, violation of the human body, living or dead, is forbidden in, for instance, Islam ${ }^{33}$ and therefore bodies are not donated for use in medical training by this group. The black population group is hesitant to donate bodies because of traditional African beliefs that the body is not separate from the soul and they need to be buried as an integrated whole. This means that, in general, black individuals are against body donation, as reflected in the relatively low percentage of skeletal material in the collection (16.5\%) as opposed to the high percentage of black individuals $(32.9 \%)$ residing in the Western Cape, according to the most recent ${ }^{7}$ population census. Socio-economic circumstances may be the reason for older white people to donate their bodies while black people are more likely to be migrating labourers with no known family in the region. In many instances, the South African coloured communities, as a result of low socio-economic circumstances, lack the means to host a funeral for the deceased and opt to donate the bodies for medical use. $^{34}$

\section{Conclusion}

Data were presented on 1161 individuals in the Kirsten Skeletal Collection, derived mainly from the cadaver donation programme over a 58-year period (1957-2015). The skeletal profile in general, despite differences in the age and sex composition of three population groups, reflects predominantly the profile of the Western Cape population. The Kirsten Skeletal Collection is unique compared to other known skeletal collections in South Africa ${ }^{1,3-5}$ in that the majority of the individuals are from the heterogeneous South African coloured population.

Current biological profile techniques in age, ancestry and sex estimation should be improved and new regional and ethnic specific standards can be developed. Researchers may contact the corresponding author for 
information regarding access to the collection for research. The Kirsten Skeletal Collection retains great potential to contribute to a wealth of future research projects in skeletal biology and related fields, and may be utilised as long as the origin of the remains is acknowledged and accounted for by the use of appropriate methods.

\section{Acknowledgements}

We thank Dolf van Rensburg, Ben Jooste and Basil Veenendal for their assistance with the development of the Kirsten Collection and Danni Perreira for editing. We also thank the anonymous reviewers for their input. A special thank you goes to the people who donated their bodies to science.

\section{Authors' contributions}

A.A. was the lead author, and collected and analysed the data and wrote the first draft. L.M.G. supervised the study and assisted with data analysis and editing. E.G. assisted with data collection. All authors contributed to critical reviewing and revision of the article and approved the final version.

\section{References}

1. Dayal MR, Kegley ADT, Strkalj G, Bidmos MA, Kuykendall KL. The history and composition of the Raymond A. Dart Collection of human skeletons at the University of the Witwatersrand, Johannesburg, South Africa. Am J Phys Anthropol. 2009;140:324-335. https://doi.org/10.1002/ajpa.21072

2. DiGangi EA, Moore MK. Research methods in humans skeletal biology. Waltham, MA: Academic Press; 2013.

3. Hunt D, Albanese J. History and demographic composition of the Robert J. Terry Anatomical Collection. Am J Phys Anthropol. 2005;127:406-417.

4. Komar D, Grivas C. Manufactured populations: What do contemporary reference skeletal collections represent? A comparative study using the Maxwell Museum Documented Collection. Am J Phys Anthropol. 2008;137:224-233. https://doi.org/10.1002/ajpa.20858

5. L'Abbé EN, Loots M, Meiring JH. The Pretoria Bone Collection: A modern South African skeletal sample. HOMO. 2005;56:197-205. https://doi. org/10.1016/j.jchb.2004.10.004

6. Stull KE, Kenyhercz MW, L'Abbé EN. Ancestry estimation in South Africa using craniometrics and geometric morphometrics. Forensic Sci Int. 2014;245,206. e1-206.e7. https://doi.org/10.1016/j.forsciint.2014.10.021

7. Statistics South Africa. Census 2011: Statistical release. Pretoria: Statistics South Africa; 2012

8. Schuster SC, Miller W, Ratan A, Tomsho LP, Giardine B, Kasson LR. Complete Khoisan and Bantu genomes from southern Africa. Nature. 2010;463:943947. https://doi.org/10.1038/nature08795

9. Chen YS, Olckers A, Schurr TG, Kogelnik AM, Huoponen K, Wallace, DC. mtDNA variation in the South African Kung and Khwe-and their genetic relationships to other African populations. Am J Hum Genet. 2000;66:13621383. https://doi.org/10.1086/302848

10. De Wit E, Delport W, Rugamika CE, Meintjes A, Möller M, Van Helden PD, et al. Genome-wide analysis of the structure of the South African coloured population in the Western Cape. Hum Genet. 2010;128:145-153. https://doi. org/10.1007/s00439-010-0836-1

11. Schlebusch CM, Skoglund P, Sjödin P, Gattepaille LM, Hernandez D, Jay $F$, et al. Genomic variation in seven Khoe-San groups reveals adaptation and complex African history. Science. 2012;338:374-379. https://doi. org/10.1126/science.1227721

12. Thompson LA. History of South Africa. New Haven, CT: Yale University Press; 2013. https://doi.org/10.1163/18757421-90000065

13. Tishkoff SA, Reed FA, Friedlaender FR, Ehret C, Ranciaro A, Froment A, et al. The genetic structure and history of Africans and African Americans. Science. 2009;324(5930):1035-1044. https://doi.org/10.1126/science.1172257
14. De Filippo C, Barbieri C, Whitten M, Mpoloka MS, Gunnarsdottir ED, Bostoen $\mathrm{K}$, et al. Y-chromosomal variation in sub-Saharan Africa: Insights into the history of Niger-Congo groups. Mol Biol Evol. 2011;28(3):1255-1269. https://doi.org/10.1093/molbev/msq312

15. Plaza S, Salas A, Calafell F, Corte-Real F, Bertranpetit J, Carracedo A, et al. Insights into the western Bantu dispersal: mtDNA lineage analysis in Angola. Hum Genet. 2004;115(5):439-47. https://doi.org/10.1007/s00439-0041164-0

16. Coelho M, Sequeira F, Luiselli D. Beleza S, Rocha J. On the edge of Bantu expansions: mtDNA, $Y$ chromosome and lactase persistence genetic variation in southwestern Angola. BMC Evol Biol. 2009;9:80. https://doi. org/10.1186/1471-2148-9-80

17. Patterson N, Petersen DC, Van der Ross RE, Sudoyo H, Glashoff RH, Marzuki $S$, et al. Genetic structure of a unique admixed population: Implications for medical research. Hum Mol Genet. 2010;19:411-419. https://doi. org/10.1093/hmg/ddp505

18. Van der Ross RE. Up from slavery: Slaves at the Cape: Their origins, treatment and contribution. Cape Town: Ampersand Press in association with the University of the Western Cape; 2005.

19. Petersen DC, Libiger O, Tindall EA, Harie RE, Hannick LI, Glashoff RH, et al. Complex patterns of genomic admixture within southern Africa. PLoS Genet. 2013;9, e1003309, 17 pages. https://doi.org/10.1371/journal.pgen.1003309

20. Jacobson CK, Amoateng AY, Heaton TB. Inter-racial marriages in South Africa. $\mathrm{J}$ Comp Fam Stud. 2004;35:443.

21. Sherman R, Steyn M. E-race-ing the line: South African interracial relationships yesterday and today. In: The prize and the price: Shaping sexualities in South Africa. Cape Town: HSRC Press; 2009.

22. McDowell J, Kenyhercz M, L'Abbé E. An evaluation of nasal bone and aperture shape among three South African populations. Forensic Sci Int. 2015;189:e1e7. https://doi.org/10.1016/j.forsciint.2015.04.016

23. Erasmus Z. Apartheid race categories: Daring to question their continued use. Transform Crit Perspect South Afr. 2012:79, 11 pages. https://doi. org/10.1353/trn.2012.0008

24. Labuschagne BCJ, Mathey B. Cadaver profile at University of Stellenbosch Medical School, South Africa, 1956-1996. Clin Anat. 2000;13:88-93. https:// doi.org/10.1002/(sici)1098-2353(2000)13:2<88::aid-ca3>3.0.c0;2-q

25. Kalmijn M. Intermarriage and homogamy: Causes, patterns. Annu Rev Sociol. 1998:395-421.

26. South African National Department of Health. Human Tissues Act. Government Gazette. 1983;216:1-34.

27. South African National Department of Health. National Policy for Health Act, 2003 (Act No. 61 of 2003). Government Gazette. 2004;469:66-79.

28. Joyner K. Aspects of forensic medicine - An introduction for healthcare professionals. Cape Town: Juta and Co Ltd.; 2010.

29. Pfeiffer S, Heinrich J, Beresheim A, Alblas M. Cortical bone histomorphology of known-age skeletons from the Kirsten Collection, Stellenbosch University, South Africa. Am J Phys Anthropol. 2016;160:137-147. https://doi. org/10.1002/ajpa.22951.

30. Holgate RL, Steyn M. Diffuse idiopathic skeletal hyperostosis: Diagnostic, clinical, and paleopathological considerations. Clin Anat. 2016:870-877. https://doi.org/10.1002/ca.22716.

31. Liebenberg L, L'Abbé EN, Stull KE. Population differences in the postcrania of modern South Africans and the implications for ancestry estimation. Forensic Sci Int. 2015;257:522-529. https://doi.org/10.1016/j.forsciint.2015.10.015

32. Steyn M, Buskes J. Skeletal manifestations of tuberculosis in modern human remains. Clin Anat. 2016:854-861. https://doi.org/10.1002/ca.22688.

33. Golmakani MM, Niknam MH, Hedayat KM. Transplantation ethics from the Islamic point of view. Med Sci Monit. 2005;11:105-109.

34. Van Tonder JL. Fertility survey 1981: Data concerning the coloured population of South Africa. Pretoria: Human Sciences Research Council; 1984. 